\title{
Farmer's Market, Demonstration Gardens, and Research Projects Expand Outreach of Extension Master Gardeners
}

\author{
Pamela J. Bennett ${ }^{1,10}$, Ellen M. Bauske ${ }^{2}$, Alison Stoven O'Connor ${ }^{3}$, \\ Jean Reeder ${ }^{3}$, Carol Busch ${ }^{4}$, Heidi A. Kratsch ${ }^{5}$, Elizabeth Leger ${ }^{6}$, \\ Angela O'Callaghan ${ }^{7}$, Peter J. Nitzsche ${ }^{8}$, and Jim Downer ${ }^{9}$
}

\begin{abstract}
AdDITIONAL INDEX WORDS. management, supervision, leadership, coordinator, volunteers

SUMMARY. Extension Master Gardener (EMG) volunteers are central to expanding the outreach and engagement of extension staff. A workshop format was used at the Annual Conference of the American Society for Horticultural Science on 31 July 2012 in Miami, FL to identify successful management techniques and projects that expand EMG volunteer outreach, leading to increased extension effectiveness. One program leader described how EMGs manage a farmer's market that has been thriving for more than 30 years, generating income for the EMG program as well as the county extension office. Another program leader described a beneficial partnership between EMGs and the university in which EMGs grow plants for demonstration gardens and classroom use, facilitating learning for university students, EMGs, and the public. EMGs in another program have assumed much of the management role of the university orchard, using it for teaching and demonstrations. The final discussion focused on extension programs that used volunteers to assist in conducting research to expand extension's capabilities, and also increasing EMGs' understanding of the research process. All projects emphasized the need for extension agents to empower volunteers to take on leadership and decision-making roles as well as the value of EMGs to extension.
\end{abstract}

$\mathrm{T}$ he EMG volunteer program originated in Washington state in 1972 when D. Gibby was overwhelmed by the volume of requests

This article was part of the workshop "Master Gardener Volunteer Program Management and Project Ideas That Work" held 31 July 2012 at the ASHS Conference, Miami, FL, and sponsored by the Consumer Horticulture/Master Gardener (CHMG) Working Group.

The authors thank Extension Master Gardeners for their dedication and commitment to Extension; this allows extension agents to expand their teaching and research to a far greater audience.

${ }^{1}$ Ohio State University Extension, 4400 Gateway Boulevard, Suite 104, Springfield, OH 45502

${ }^{2}$ Center for Urban Agriculture, University of Georgia, 1109 Experiment Street, Griffin, GA 30223

${ }^{3}$ Colorado State University Extension, 1525 Blue Spruce Drive, Fort Collins, CO 80524

${ }^{4}$ Colorado State University Extension, 4040 Campus Delivery, Fort Collins, CO 80523

${ }^{5}$ University of Nevada Cooperative Extension, 4955 Energy Way, Reno, NV 89502

${ }^{6}$ Department of Natural Resources and Environmental Science, University of Nevada, Reno, 1664 N. Virginia Street, Reno, NV 89557

${ }^{7}$ University of Nevada Cooperative Extension, 8050 Paradise Road, Las Vegas, NV 89123

${ }^{8}$ Cooperative Extension of Morris County, Rutgers New Jersey Agricultural Experimental Station, P.O Box 900, Morristown, NJ 07963

${ }^{9}$ University of California Cooperative Extension, Ventura, CA 93003

${ }^{10}$ Corresponding author. E-mail: bennett.27@osu.edu. for gardening information (Meyer, 2007). Gibby developed and implemented a program whereby volunteers were trained by extension staff and faculty to provide research-based gardening information to the public. The EMG training program has spread to all 50 states, the District of Columbia and four Canadian provinces (National Master Gardener Committee, 2013). Today, most EMG programs are affiliated with a land-grant university and its extension system. The university programs train and certify EMGs to disseminate research-based information to the public. The program has an educational emphasis, avoiding promotion of commercial products or entities. According to the last Cooperative State Research, Education, and Extension Service agency report (2009), there were $\approx 94,865$ active EMGs in the United States and
Canada. EMGs annually contributed $\approx 5,197,573 \mathrm{~h}$ of volunteer work to their extension organizations on a variety of projects.

While the original intent of the EMG program was to use these volunteers to assist with horticulture phone calls (Meyer, 2007), the scope of their activity has expanded over the years. Projects now include "proactive and community based projects such as setting up exhibits, writing news articles, participating in community gardens, Yards and Neighborhood environmental programs, public demonstration gardens, community plantings and control of invasive plants" as noted in the EMG White Paper (National Master Gardener Committee, 2013). The list of activities and projects continues to expand as extension professionals use volunteers to help manage projects and programs, increasing outreach with limited staff and resources. Innovative projects continue to expand the role of EMG volunteers in extension and research activities.

\section{Materials and methods}

A workshop was held at the Annual Conference of ASHS on 31 July 2012 in Miami, FL, (Bennett, 2012) and $\approx 20$ people attended. The workshop started with two formal presentations highlighting successful projects; these presentations were the Larimer County Farmers' Market and Nevada Master Gardener Facilitates On-Campus Learning. Participants attending the workshop were then invited to share successful projects, and three additional projects were discussed. This article includes a summary of the two formal presentations and three other topics, as well as relevant discussion.

\section{Results and discussion Larimer County Colorado Farmers' Market}

Farmers' markets have increased in popularity for the past several years. In 2012, the U.S. Department of

\begin{tabular}{llll}
\hline $\begin{array}{l}\text { Units } \\
\begin{array}{l}\text { To convert U.S. to SI, } \\
\text { multiply by }\end{array}\end{array}$ & U.S. unit & SI unit & $\begin{array}{l}\text { To convert SI to U.S., } \\
\text { multiply by }\end{array}$ \\
\hline 0.4047 & acre $(\mathrm{s})$ & $\mathrm{ha}$ & 2.4711 \\
0.3048 & $\mathrm{ft}$ & $\mathrm{m}$ & 3.2808 \\
0.4536 & $\mathrm{lb}$ & $\mathrm{kg}$ & 2.2046
\end{tabular}


Agriculture (USDA) reported that there were 7864 farmers' markets in the United States compared with 1755 reported in 1994 , and a $9.6 \%$ increase from 2011 (USDA, 2012). The USDA estimates that farmers' markets are now a $\$ 1$ billion industry (Shaffer and Cox, 2006). Farmers' markets provide many benefits, including helping consumers connect with local farmers to purchase fresh, local food products, and community and economic development (Gale, 1997).

The Larimer County Farmers' Market in Fort Collins, CO, was started in the mid-1970s by Colorado State University EMGs in Larimer County, with support from Larimer County Extension. More than 35 years later, EMGs remain the backbone of the market-now one of the most successful volunteer-managed markets in the state. Extension's fiscal and administrative oversight has increased over the years as the market's season, vendor numbers, and community interests have grown. The Larimer County Farmers' Market is an EMG project that exists because of their volunteer commitment. EMGs created the market logo, maintain the website and Facebook (Menlo Park, $\mathrm{CA})$ page, assist with marketing plans, provide leadership, serve as community liaisons, and provide a wealth of information that customers can access each market day.

Today, the market is open on Saturday mornings in downtown Fort Collins, from May through October; in 2012, the market expanded from 17 to 24 weeks. Each week, up to 75 vendors sell their products. Vendors include local and direct market farmers, as well as value-added food producers and artisans. The market provides an educational venue for Cooperative Extension. Both EMGs and Larimer County Extension Master Food Safety Advisors staff the extension information booth to answer customer questions about growing and preserving food. Each week, five EMGs set up and take down the market under the direction of an EMG "Market Master" and an EMG "Assistant Market Master." Seven EMGs are needed for each market, with a total volunteer hour requirement of $32 \mathrm{~h}$ each Saturday or $\approx 768 \mathrm{~h}$ each season.

During the market, EMGs assist customers purchasing Supplemental
Nutrition Assistance Program (SNAP) benefits coupons or same-as-cash "Market Bucks." At the end of each market, EMGs collect taxes (city and state) and fees ( $6 \%$ of sales) from vendors.

In 2006, market sales totaled $\$ 222,307$ and by 2012 , market sales increased to $\$ 581,203$. Income generated from the 2012 Larimer County Farmers' Market provided $\$ 31,000$ in revenue for Larimer County Extension, which has helped offset state and local budget shortfalls.

As sponsor of the Larimer County Farmers' Market for more than three decades, Larimer County Extension and its Colorado EMGs have created a community asset that benefits the public on many levels. Specifically, the Larimer County Farmers' Market serves as a small business incubator for direct market farmers; helps to expand food security and food safety; and promotes agricultural literacy, locally grown foods, and community development. The Larimer County Farmers' Market serves as a dynamic venue for educating the public. Vendors refer customers with gardening questions to EMGs; EMGs likewise refer customers back to vendors for pricing and food availability. It has become a community hub, linking consumers and producers through business and social relationships. Accepting SNAP coupons has expanded access for purchasing of fresh, nutritious, and locally grown food, regardless of income level. Use of SNAP benefits coupons has increased nearly 7 -fold since first introduced in 2007.

The Larimer County Farmers' Market also provides additional benefits to the Larimer County Extension program as well as the community. The market provides a low-risk retail venue for entrepreneurs who want to put business plans in place; the cost to apply is $\$ 50$. Financial accessibility promotes diverse participation, from new to well-established regional growers, and offers producers the chance to compete, grow, and diversify. Most vendors donate unsold produce to the Larimer County Food Bank; in 2012, donations topped $4500 \mathrm{lb}$.

Managing a long-season market of this size has its challenges. Because the market workforce depends solely on EMGs for day-to-day operations, burnout is a concern. It requires careful balance to keep EMGs motivated and engaged. Encouragement and gratitude from extension office personnel, as well as from vendors and customers is important. Periodic customer surveys reveal that most customers are unaware that Larimer County Extension staff and EMGs completely manage the market. EMGs continue to work on linking the market and associated activities with Larimer County Extension outreach and programming efforts. Larimer County recognizes these many benefits and is proud to partner with Colorado State University Extension in providing this community asset.

\section{Nevada Master Gardeners Facilitate On-campus Student Learning}

EMG programs across the United States are often challenged to keep their EMGs connected to the university and to the outreach mission of Cooperative Extension (Bauske et al., 2011). This challenge can be compounded by university faculty and administrators, who may not be aware of the value of such programs to the university, faculty, students, and the community. An innovative agreement between the College of Agriculture, Biotechnology, and Natural Resources and the College of Cooperative Extension at the University of Nevada, Reno, is helping to bridge this gap and enrich teaching, extension, and EMG programs.

At the University of Nevada, Reno, EMGs grow five species of native plants for the Natural Resource and Environmental Science class (NRES 345, Range and Forest Plants). In exchange for their efforts, EMGs are given year-round use of a $25 \times$ 25 - $\mathrm{ft}$ bay within the teaching greenhouse facility on campus. EMGs have an opportunity to interact directly with university research and teaching faculty, as well as students, through this arrangement. The resulting collaboration expands volunteer opportunities for EMGs, facilitates on-campus student learning, and increases visibility of the University of Nevada Cooperative EMG program while assisting teaching faculty with their workload.

This agreement recognizes that faculty within the University of Nevada, Reno's Department of Natural 
Resources and Environmental Science and EMG volunteers have similar interests in native plant ecology and use. This agreement has proven to be a win-win for EMGs and campus faculty and, as a result, both have expanded and increased their capacity and outreach. One of the main reasons people volunteer to become an EMG is to learn more about horticulture and gardening (Wilson and Newman, 2011). Therefore, EMGs are excited to have an opportunity to connect with research and teaching faculty.

The Northern Nevada EMG Native Plants Club was established to provide outreach education to the public regarding the value of native plants from the Great Basin ecoregion. The goal is to highlight the ecological services native plants provide. Native plants conserve landscape water, preserve wildlife habitat, and provide food and shelter for native pollinators in urban environments. Outreach efforts by the Native Plants Club were limited to extension publications, newspaper articles, and presentations at garden club meetings before the formal agreement with University of Nevada, Reno.

As a result of the agreement, the Native Plants Club EMGs have access to the state-of-the-art, professionally managed greenhouse facility on campus where the EMGs are propagating and growing native plants. The university students and faculty also benefit from the agreement. Live plants, grown by EMGs, are used in both classes and exams in the undergraduate Range and Forest Plants class taught by E. Leger. The class has an average enrollment of 50 students. In the past, fresh specimens were only available at the beginning of the course, with dried native specimens or purchased horticultural varieties the only option toward the end of the semester. Dried specimens can be used during laboratories, but they are difficult to use for testing purposes, and horticultural varieties often have atypical flower parts and are not representative of the family to which they belong. Plants from strategically selected species representing major plant families prevalent in the southern Great Basin ecoregion are grown for class use. Flowers of these plants are used as part of the final exam for students in the
University of Nevada, Reno's Range and Forest Plant Identification class. EMG volunteers also grow native annual species, allowing the instructor to evaluate the students' ability to key out species based on identifying characteristics, rather than their ability to memorize species names based on gross morphology.

EMGs also use the greenhouse facility to grow native plants for public education classes, demonstration gardens, and the annual EMG plant sale. In May 2012, a native plant demonstration garden was installed at Heritage Park in Gardnerville, NV. This location is a city-supported community garden managed by EMGs and other community volunteers. Another is planned for space adjacent to the University of Nevada, Reno greenhouse facility in Reno, NV. The rich intellectual climate of the university has encouraged a unique and information-rich garden design at the University of Nevada, Reno campus. The campus-based garden will reflect native plant communities within elevation gradients present in the southern Great Basin ecoregion. Interpretative signs will provide information about native plant community ecology, adaptive morphology, and highlight their low water requirements. This garden space is accessible to the public, and may be used by a variety of classes for educational purposes.

In addition to learning about native plant communities, EMGs in the Native Plants Club learn about greenhouse management and irrigation systems. Under the guidance of faculty, EMGs learn how to design and build the irrigation systems suitable for native plant propagation. This is done through informal work sessions in the greenhouse with EMGs and extension faculty. They also learn about identifying native plants in the field from the herbarium staff and have the opportunity to visit the campus herbarium.

This project fosters EMG involvement with faculty and students on campus and increases learning opportunities for participating EMGs and university students. Other agencies, including the Nevada Fish and Wildlife Office, expressed an interest in collaborating to design and build native plant demonstration gardens across the community.

\section{Project ideas presented as part of discussion in workshop \\ VOLUNTEER MANAGEMENT OF AN} ORCHARD. EMG volunteers revitalized and assumed the management role of an orchard in Clark County, Las Vegas, NV. The orchard began as a faculty demonstration project in 1994, according to Angela O'Callaghan, Social Horticulture Specialist for the University of Nevada Extension. The orchard is 5 acres and contains 450 fruit trees, both traditional [apple (Malus $\times$ domestica), peach (Prunus persica), and pear (Pyrus communis)], and more desert-adapted trees, such as pomegranate (Punica granatum) and fig (Ficus carica). The orchard is used as a venue for extension to accomplish the mission of bringing unbiased information to the public in a nonclassroom setting. It is the only site in the region that is dedicated to teaching the public about the varieties of fruit and vegetables that will succeed in the Mojave Desert climate as well as cultural practices necessary to maintain the trees. EMGs teach formal classes at the orchard, as well as participate in informal instruction to the public who visit either to purchase produce or to obtain horticultural information. The orchard is open to the public only on the $3 \mathrm{~d}$ (Tuesday, Thursday, and Saturday), when EMGs are present. The EMGs receive ongoing training from University of Nevada Extension faculty and from outside specialists.

EMGs initially volunteered to assist faculty and work in the orchard; however, they now orchestrate allimportant functions, including management, sales, and maintenance. Because of the climate in the region, the orchard requires a considerable amount of labor. The EMGs now maintain the trees, harvest the fruit, and offer the produce to the public with a suggested donation. These donations average around $\$ 10,000$ annually. The funds are placed in an orchard sales account and are used to help cover some of the costs of plants and equipment. Unsold fruit is donated to the local food bank; $\approx 500 \mathrm{lb}$ was donated in 2012. EMGs regularly teach individuals and small groups about horticulture in the Mojave Desert as well as how to grow fruit and vegetables at their own homes.

The orchard coordinating committee is an elected group of EMGs 
who have a regular commitment (one to three times per week) to work in the orchard. This is used to fulfill their 35-h minimum project credit requirement. A faculty member supervises the farm manager who designs the plan of work for the season, directs EMGs in tasks, orders plants, applies horticultural chemicals, and deposits money donated for the produce. The EMGs meet weekly with the faculty member and farm manager. In addition to educational presentations from faculty or other experts in the field, the EMGs receive updates on the most pressing tasks (e.g., insect control, pruning, and replacing trees). They receive continuing education units for this to meet the requirement to be a certified EMG.

UsING EMGs To ASSIST wITH EXTENSION RESEARCH. Several workshop participants indicated EMGs participate in their research programs. This arrangement is mutually beneficial. Researchers benefit from the skilled and knowledgeable manpower. EMGs increase their understanding of the research process and extension delivery of research results. The close interaction with researchers can increase volunteer loyalty to the land-grant institution and empower volunteers as they deal with the myriad of assertions and assumptions that riddle popular horticulture.

Peter Nitzsche, Morris County Agricultural Agent with Rutgers New Jersey Agricultural Experiment Station, Morristown, NJ works with his EMGs in a project that involves variety trials and informal taste tests. Because of the increase in interest in local foods, clientele seek the besttasting varieties for home gardens and small farms. EMGs assist Nitzsche in harvesting fruit from his tomato (Solanum lycopersicum) variety trials. The EMGs then help him perform informal taste tests at local farmers' markets. The volunteers take the tomatoes and supplies for the taste tests to the various farmers' markets and set up for the activity.

Nitzsche developed a Likert scale that focused on sweetness, acidity, and overall flavor in tomatoes. There are six coded variety samples and the public provides their feedback on a written form. The small (grapesized) tomatoes are well suited for taste tests as they are used whole, therefore limiting the possibility of food safety issues. Toothpicks are used to pick up individual tomatoes. EMGs supervise this process to ensure testing credibility. The results of the taste tests are presented to farmers at winter educational meetings and posted on extension websites for the public to review.

Nitzsche has also worked with EMGs to develop a tomato variety trial and a proper pruning practices demonstration in a community garden. EMGs helped plant and maintain vegetables, and gather yield, fruit size, and quality data from the demonstration. EMGs also helped develop educational signage for the plot. Community gardeners learned proper tomato culture through interactions with EMGs as well as about Cooperative Extension and the various services provided. The harvested produce was donated to a food bank (269 lb in 2012).

Dr. Jim Downer, Director/Farm Advisor, University of California Extension, Ventura County, Ventura, CA, involves EMGs in rose research. EMGs have pruned roses and gathered varietal and quality data for 5 years. He provided training to lead EMGs who have taken on a larger role in this project. They organize the research project and provide leadership to other EMGs. By involving the EMGs in the organizational role, they have a greater understanding of how to conduct research. In addition, an agent's ability to take on larger research projects increases when EMGs can take on tasks such as pruning, rating, and managing a larger number of plants.

Nitzsche and Downer both noted that research projects in which volunteers played leadership roles, making decisions and suggestions, were more successful than projects in which EMGs had little input. As is often the case, a sense of ownership was important. Publicly acknowledging EMG contributions was also important.

\section{Conclusion}

EMG volunteers play a key role in expanding the outreach and engagement efforts of Cooperative Extension specialists and agents. EMGs typically answer telephones, work in demonstration gardens, and assist with providing educational programs. This workshop highlighted projects that have expanded the role of EMGs and simultaneously increased extension outreach.

These successful outreach efforts had three consistent characteristics: the projects allowed the EMGs to continue learning and interacting with the public; the contribution of the volunteers was clearly recognized; and extension specialists/agents were required to relinquish control of the outreach/research effort.

One of the strongest reasons people volunteer to become an EMG is to learn more about horticulture and gardening (Strong and Harder, 2010; Wilson and Newman, 2011). All of these successful projects allowed the EMG volunteers to continue learning and applying that knowledge, regardless of whether they were answering inquiries in a market or growing plants in a university greenhouse.

Recognition and praise have a strong correlation with the level of involvement of EMG volunteers (Schrock et al., 2000). All workshop participants acknowledged the important role this played in the success of these projects and programs.

According to Snider (1985) "Extension programs are strongest when a partnership and a balance of program ownership and responsibilities exist between extension professionals and key volunteers." The projects presented here required agents to shift roles, from that of a program implementer to that of a program leader, and this can present challenges. It requires the extension professional to possess the skills necessary to train volunteers to be capable of handling necessary tasks (Clemens et al., 2007). Agents typically enter extension with competencies in a content area such as youth development, agriculture, horticulture, community development, and family and consumer sciences. They often lack those competencies needed to be effective volunteer managers or administrators (Boyd, 2004). Boyd (2004) also noted that extension uses volunteers extensively in every program area. As we rely heavily on volunteers to extend outreach and engagement, program leaders need to have an understanding of managing and developing volunteers to succeed.

\section{Literature cited}

Bauske, E.M., L. Kelly, K. Smith, L. Bradley, T. Davis, and P.J. Bennett. 
2011. Increasing effectiveness of cooperative extension's Master Gardener volunteers. HortTechnology 21:150-154.

Bennett, P.J. 2012. Master Gardener volunteer program management and project ideas that work. HortScience 47:S84S85. (Abstr.).

Boyd, B. 2004. Extension agents as administrators of volunteers: Competencies needed for the future. J. Ext. 42(2). 21 Feb. 2013. <http://www.joe.org/joe/ 2004april/a4.php>.

Clemens, S.S., B.R. Swistock, and W.E. Sharpe. 2007. The master well owner network: Volunteers educating Pennsylvania well owners. J. Ext. 45(4). 3 Feb. 2013. <http://www.joe.org/joe/ 2007august/rb7.php>.

Cooperative State Research Education and Extension Service. 2009. 2009 Extension Master Gardener survey. 21 Feb. 2013. <http://www.extension.org/
mediawiki/files/f/f5/Extension_MG_ Survey_4-9.pdf $>$.

Gale, F. 1997. Farm-to-consumer direct marketing as a rural development tool. Rural Dev. Perspectives 12(2):19-25.

Meyer, M.H. 2007. The Master Gardener program 1992-2005. Hort. Rev. 33:393420.

National Master Gardener Committee. 2013. EMG white paper. 2 Feb. 2013. <http://www.extension.org/pages/ 14004/emg-white-paper>.

Schrock, D.S., M. Meyer, P. Ascher, and M. Snyder. 2000. Reasons for becoming involved as a Master Gardener. HortTechnology 10:626-630.

Shaffer, J. and B. Cox. 2006. USDA releases new farmers' market statistics. U.S. Dept. Agr., Agr. Mktg. Serv., Washington, DC.
Snider, A. 1985. The dynamic tension: Professionals and volunteers. J. Ext. 23(3). 3 Feb. 2013. <http://www.joe. org/joe/1985fall/sa2.php >.

Strong, R. and A. Harder. 2010. Motivational orientations of adults participating in a Cooperative Extension Master Gardener program. J. Ext. 48(4). 18 Feb. 2013. <http://www.joe.org/joe/ 2010 august/rb2.php $>$.

U.S. Department of Agriculture. 2012. Farmers markets and direct-to-consumer marketing. 30 Jan. 2013. <http:// www.ams.usda.gov/AMSvl .0/ farmersmarkets $>$.

Wilson, J.C. and M.E. Newman. 2011. Reasons for volunteering as a Mississippi Master Gardener. J. Ext. 49(5). 18 Feb. 2013. <http://www.joe.org/joe/ 201 loctober/rbl.php $>$. 